
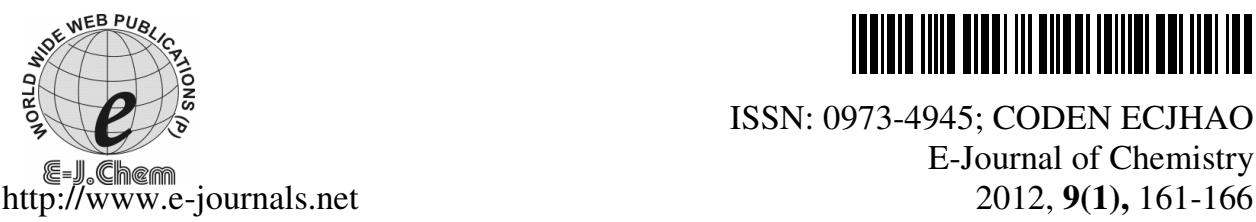

ISSN: 0973-4945; CODEN ECJHAO

E-Journal of Chemistry 2012, 9(1), 161-166

\title{
Synthesis and Characterization of Mono- and Bicycle Heterocyclic Derivatives Containing 1, 2, 4-Triazole, 1,3,4-Thiadiazine and 1,3-Thiazole Rings
}

\author{
NAVABEH NAMI ${ }^{*}$, MEHDI FOROZANI ${ }^{\S}$, \\ VIDA KHOSRAVIMOGHADAM $^{\S}$ and RAHMATALLAH TAHERINASAB \\ *Department of Chemistry, Islamic Azad University \\ Qaemshahr Branch, Qaemshahr, Mazandarn, Iran \\ ${ }^{\S}$ Department of Chemistry \\ Faculty of Sciences, Payame Noor University, Sari, Iran \\ Department of Chemistry \\ Uoromia Universits, Uoromia, West Azarbayjan, Iran \\ navabehnami@yahoo.com
}

Received 13 June 2011; Accepted 13 August 2011

\begin{abstract}
Reaction of tartaric acid with thiocarbohydrazide (2) and thiosemicarbazide (6) afforded 1,2-bis(4-amino-5-mercapto-4H-1,2,4-triazol3-yl)-ethane-1,2-diol (3) and 1,2-bis(5-mercapto-4H-1,2,4-triazol-3-yl)-ethane1,2-diol (7). Reaction of compounds 3 and 7 with DMAD (dimethylacety lendi carboxylate) and DEAD (diethylacetylendicarboxylate) gave 1,2-bis(7-[(z)methoxycarbonylmethylen]-5,6-dihydro-5H-6-one-[1,2,4] riazolo[3,4-b] [1,3,4] thiadiazin-3-yl)-ethan-1,2-diol (4), 1,2-bis(7-[(z)-ethoxycarbonylmethylen] -5,6-dihydro -5H-6-one-[1,2,4]triazolo[3,4-b][1,3,4]thiadiazin-3-yl)-ethan-1,2- diol (5) and 1,2bis(6-[(z)-methoxycarbonylmethylen]-5-oxo-[1,3]thiazolo[2,3-c] [1,2,4]triazol3-yl)-ethan-1,2-diol (8) in good yields.
\end{abstract}

Keywords: Tartaric acid, Thiocarbohydrazide, Thiosemicarbazide, [1,3]Thiazolo[2,3-c][1,2,4]triazol, $[1,2,4]$ Triazolo[3,4-b][1,3,4]thiadiazin Synthesis

\section{Introduction}

During recent years there have been investigation of different classes of 1,3,4- thiadiazines derivatives, many of which have demonstrated a broad spectrum of biological activity in both agrochemical and pharmaceutical fields showing antibacterial, antimicrobial, insecticidal, herbicidal/fungicidal and antitumor activity ${ }^{1-2}$. In addition, compounds incorporating 1,2,4-triazole and 1,3-thiazole rings have been attracting widespread attention 
due to their diverse pharmacological properties such as antimicrobial, anti-inflammatory, analgesic and antitumor activities ${ }^{3-4}$. The incorporation of various substituents into the 1,2,4-triazole ring and it's fusion with various heterocyclic systems yield compounds with enhanced biological activities ${ }^{5-10}$. Some 3,6-disubstituted 1,2,4-triazolo[3,4-b]1,3,4-thiadiazine derivatives showed anti-HIV-1 activity at concentration slightly below cytotoxic levels ${ }^{11}$.

Consequently, in view of the above facts and as a part of an ongoing investigation into biologically more active and less toxic substances, our current interest is focused on the synthesis of a series of new 1,2,4-triazole, condensed 1,2,4-triazolothiadiazine and 1,3-thiazolotriazole derivatives.

\section{Experimental}

All of the chemical materials and solvents were purchased from Merck Chemical Company. The melting points were obtained using an Electrothermal IA 9100 digital melting point apparatus. The IR spectra were recorded on a Bruker IFS- 88 instrument (the samples as $\mathrm{KBr}$ disks for the range $4000-400 \mathrm{~cm}^{-1}$ ). The ${ }^{1} \mathrm{H}$ and ${ }^{13} \mathrm{C}$ NMR spectra were recorded on a Bruker AC-300 spectrometer $\left({ }^{1} \mathrm{H}, 400 \mathrm{MHz} ;{ }^{13} \mathrm{C}, 75.469 \mathrm{MHz}\right)$ using TMS as an internal standard. Mass spectrometric measurements were made on an agilent technologies $6890 \mathrm{~N}$ Network GC system. The C, H and N analyses were performed by the microanalytical service of the NIOC research institute of petroleum industry.

\section{1,2-Bis(4-amino-5-mercapto-4H-1,2,4-triazol-3-yl)-ethane-1,2-diol (3)}

The compound 3 was synthesized by using the reported procedure ${ }^{16}$.

\section{1,2-Bis(7-[(z)-methoxycarbonylmethylen]-5,6-dihydro-5H-6-one-[1,2,4]triazolo[3,4-b]} [1,3,4]thiadiazin-3-yl)-ethan-1,2-diol (4)

A solution of 1,2-bis(4-amino-5-mercapto-4H-1,2,4-triazol-3-yl)-ethane-1,2-diol 3 (1 mmol, $0.290 \mathrm{~g}$ ) and DMAD ( $2 \mathrm{mmol}, 0.284 \mathrm{~g}$ ) in $20 \mathrm{~mL}$ of $\mathrm{MeOH}$ was heated under reflux condition for $2 \mathrm{~h}$. The progress of the reaction was monitored by TLC, using methanol/ethylacetate 1:4. The solvent was removed under reduced pressure. The precipitate was recrystallized with ethylacetate to give compound 4. Yield 73\%, m.p. 156-157 ${ }^{\circ} \mathrm{C}, \mathrm{R}_{\mathrm{f}}=0.3$, yellow powder. Anal. Calcd. For $\mathrm{C}_{16} \mathrm{H}_{14} \mathrm{~N}_{8} \mathrm{O}_{8} \mathrm{~S}_{2}$ : C, 37.65; H, 2.76; N, 21.95. Found: C, 37.42; H, 2.81; N, 22.35. MS: $m / z, 510\left(\mathrm{M}^{+}\right)$. IR $(\mathrm{KBr})\left(v_{\max } \mathrm{cm}^{-1}\right): 3370(\mathrm{NH}), 1730(\mathrm{C}=\mathrm{O}), 1665(\mathrm{C}=\mathrm{O}) .{ }^{1} \mathrm{H}-\mathrm{NMR}: \delta$ $\left(\mathrm{d}_{6}\right.$-DMSO), $3.82\left(\mathrm{~s}, 3 \mathrm{H}, \mathrm{CH}_{3}\right), 4.14(\mathrm{~s}, 1 \mathrm{H}, \mathrm{OH}), 5.46(\mathrm{~s}, 1 \mathrm{H}, \mathrm{CH}), 6.96(\mathrm{~s}, 1 \mathrm{H}, \mathrm{CH}), 7.27$ $(\mathrm{s}, 1 \mathrm{H}, \mathrm{NH}),{ }^{13} \mathrm{C}-\mathrm{NMR}: \delta\left(\mathrm{d}_{6}-\mathrm{DMSO}\right), 51.42\left(\mathrm{OCH}_{3}\right), 72.88(\mathrm{CH}-\mathrm{OH}), 141.24(\mathrm{CH}=\mathrm{C})$, $147.55(\mathrm{C}=\mathrm{N}), 153.35(\mathrm{C}=\mathrm{N}), 159.60(\mathrm{C}=\mathrm{CH}), 162.17(\mathrm{C}=\mathrm{O}), 164.68(\mathrm{C}=\mathrm{O})$.

\section{1,2-Bis(7-[(z)-ethoxycarbonylmethylen]-5,6-dihydro-5H-6-one-[1,2,4]triazolo[3,4-b]} [1,3,4]thiadiazin-3-yl)-ethan-1,2-diol (5)

A solution of 1,2-bis(4-amino-5-mercapto-4H-1,2,4-triazol-3-yl)-ethane-1,2-diol 3 (1 mmol, $0.266 \mathrm{~g})$ and DEAD ( $2 \mathrm{mmol}, 0.340 \mathrm{~g})$ in $20 \mathrm{~mL}$ of EtOH was heated under reflux condition for $2 \mathrm{~h}$. The progress of the reaction was monitored by TLC, using methanol/ ethylacetate 1:4. The solvent was removed under reduced pressure. The precipitate was recrystallized with ethylacetate to give compound 5. Yield 77\%, m.p. 173-174 ${ }^{\circ} \mathrm{C}, \mathrm{R}_{\mathrm{f}}=0.4$, yellow powder. Anal. Calcd. For $\mathrm{C}_{18} \mathrm{H}_{18} \mathrm{~N}_{8} \mathrm{O}_{8} \mathrm{~S}_{2}$ : C, 40.15; H, 3.37; N, 20.81. Found: C, 39.98; H, 3.44; N, 20.56. MS: $\mathrm{m} / \mathrm{z} 538\left(\mathrm{M}^{+}\right)$. IR $(\mathrm{KBr})\left(v_{\max } \mathrm{cm}^{-1}\right): 3100(\mathrm{NH}), 1721(\mathrm{C}=\mathrm{O})$, $1676(\mathrm{C}=\mathrm{O}), 1652(\mathrm{C}=\mathrm{N}), 1635(\mathrm{C}=\mathrm{C}) .{ }^{1} \mathrm{H}-\mathrm{NMR}: \delta\left(\mathrm{d}_{6}\right.$-DMSO), $1.19\left(\mathrm{t}, J=8.5,3 \mathrm{H}, \mathrm{CH}_{3}\right.$, ), $4.11\left(\mathrm{q}, J=8.5,2 \mathrm{H}, \mathrm{CH}_{2}\right), 4.80(\mathrm{~s}, 1 \mathrm{H}, \mathrm{OH}), 5.23(\mathrm{~s}, 1 \mathrm{H}, \mathrm{CH}), 6.99(\mathrm{~s}, 1 \mathrm{H}, \mathrm{CH}), 7.10(\mathrm{~s}, 1 \mathrm{H}$, $\mathrm{NH}) .{ }^{13} \mathrm{C}-\mathrm{NMR}: \delta\left(\mathrm{d}_{6}\right.$-DMSO $), 17.41\left(\mathrm{CH}_{3}\right), 50.35\left(\mathrm{CH}_{2}\right), 71.92(\mathrm{CH}-\mathrm{OH}), 139.24(\mathrm{CH}=\mathrm{C})$, 145,56 $(\mathrm{C}=\mathrm{N}), 151.20(\mathrm{C}=\mathrm{N}), 157.63(\mathrm{C}=\mathrm{CH}), 159.13(\mathrm{C}=\mathrm{O}), 163.26(\mathrm{C}=\mathrm{O})$. 


\section{1,2-Bis(5-mercapto-4H-1,2,4-triazol-3-yl)-ethane-1,2-diol (7)}

A solution of tartaric acid $(1 \mathrm{mmol}, 0.150 \mathrm{~g})$ in dry pyridine $(5.0 \mathrm{~mL})$ was treated with thiosemicarbazide $(2 \mathrm{mmol}, 0.182 \mathrm{~g}$ ). The reaction mixture was heated under reflux for $1.5 \mathrm{~h}$ whereby a solid product formed. It was left to cool, filtered, washed with methanol and crystallized with methanol and water (1:2). Yield $68 \%$, m.p. $135-136^{\circ} \mathrm{C}, \mathrm{R}_{\mathrm{f}}=0.5$ by $n$-hexane/ethylacetate 1:4, white powder. Anal. Calcd. For $\mathrm{C}_{6} \mathrm{H}_{8} \mathrm{~N}_{6} \mathrm{O}_{2} \mathrm{~S}_{2}: \mathrm{C}, 27.69 ; \mathrm{H}, 3.10 ; \mathrm{N}$, 32.29. Found: C, 27.49; H, 2.97; N, 32.11. MS: $m / z 260\left(\mathrm{M}^{+}\right)$. IR $(\mathrm{KBr})\left(v_{\max } \mathrm{cm}^{-1}\right): 3150(\mathrm{NH})$, $1630(\mathrm{C}=\mathrm{N}) .{ }^{1} \mathrm{H}-\mathrm{NMR}: \delta\left(\mathrm{d}_{6}\right.$-DMSO), $2.57(\mathrm{~s}, 1 \mathrm{H}, \mathrm{SH}), 4.28(\mathrm{~s}, 1 \mathrm{H}, \mathrm{OH}), 4.79(\mathrm{~s}, 1 \mathrm{H}, \mathrm{CH})$, $7.02(\mathrm{~s}, 1 \mathrm{H}, \mathrm{NH}) .{ }^{13} \mathrm{C}-\mathrm{NMR}: \delta\left(\mathrm{d}_{6}-\mathrm{DMSO}\right), 75.39(\mathrm{CH}-\mathrm{OH}), 143.03(\mathrm{C}=\mathrm{N}), 156.25(\mathrm{C}=\mathrm{N})$.

\section{1,2-Bis(6-[(z)-methoxycarbonylmethylen]-5-oxo-[1,3]thiazolo[2,3-c][1,2,4]triazol-} 3-yl)-ethan-1,2-diol (8)

A solution of 1,2-bis(5-mercapto-4H-1,2,4-triazol-3-yl)-ethane-1,2-diol 7 (1 mmol, $0.260 \mathrm{~g}$ ) and DMAD (2 mmol, $0.284 \mathrm{~g})$ in $\mathrm{MeOH}(10 \mathrm{~mL})$ was heated under reflux condition for $2 \mathrm{~h}$. The progress of the reaction was monitored by TLC, using methanol/ethylacetate 1:4. The solvent was removed under reduced pressure. The precipitate was recrystallized with ethylacetate to give compound $\mathbf{8}$.

Yield $48 \%$, m.p. $187-188{ }^{\circ} \mathrm{C}, \mathrm{R}_{\mathrm{f}}=0.3$, yellow powder. Anal. Calcd. For $\mathrm{C}_{16} \mathrm{H}_{12} \mathrm{~N}_{6} \mathrm{O}_{8} \mathrm{~S}_{2}$ : C, 40.60; H, 2.52; N, 17.49. Found: C, 40.83; H, 2.41; N, 17.68. MS: $\mathrm{m} / \mathrm{z} 480\left(\mathrm{M}^{+}\right)$. IR $(\mathrm{KBr})\left(v_{\max } \mathrm{cm}^{-1}\right): 1715(\mathrm{C}=\mathrm{O}), 1680(\mathrm{C}=\mathrm{O}), 1625(\mathrm{C}=\mathrm{N}) .{ }^{1} \mathrm{H}-\mathrm{NMR}: \delta\left(\mathrm{d}_{6}\right.$-DMSO), 3.99 $\left(\mathrm{s}, 3 \mathrm{H}, \mathrm{CH}_{3}\right), 5.07(\mathrm{~s}, 1 \mathrm{H}, \mathrm{OH}), 5.23(\mathrm{~s}, 1 \mathrm{H}, \mathrm{CH}), 6.60(\mathrm{~s}, 1 \mathrm{H}, \mathrm{CH}) .{ }^{13} \mathrm{C}-\mathrm{NMR}: \delta\left(\mathrm{d}_{6}-\mathrm{DMSO}\right)$, $54.11\left(\mathrm{CH}_{3}\right), 73.65(\mathrm{CH}-\mathrm{OH}), 134.57(\mathrm{CH}=\mathrm{C}), 144.98(\mathrm{C}=\mathrm{N}), 148.62(\mathrm{C}=\mathrm{N}), 147.41$ $(\mathrm{C}=\mathrm{CH}), 160.37(\mathrm{C}=\mathrm{O}), 163.50(\mathrm{C}=\mathrm{O})$.

\section{Results and Discussion}

The synthesis of 4-amino-5-mercapto-1,2,4-triazoles can be achieved by the cyclization of an acylthiocarbazinic acid or a thiocarbohydrazide ${ }^{12-15}$. In order to approach the synthesis of the target compounds, dehydrative cyclization of equimolar amounts of tartaric acid with thiocarbohydrazide (2) or thiosemicarbazide (6) in pyridine gave 1,2-bis (4-amino-5mercaprto-4H-1,2,4-triazol-3-yl)-ethane-1,2-diol (3) and 1,2-bis(5-mercapto-4H-1,2,4-triazol3-yl)-ethane-1,2-diol (7), respectively.

The reaction proceeds through a nucnucleophilic attack of $N-1$ of the thiocarbohydrazide or thiosemicarbazide on the carbonyl carbon, then by futher nucleophilic attack of the $N-3$ to the carbonyl carbon and subsequent dehydration of the cyclized intermediate to give $\mathbf{3}^{16}$ and $\mathbf{7}$ (Scheme 1, 2). Reaction of compound 3 with DMAD (dimethylacetylendicarboxylate) and DEAD (diethylacetylendicarboxylate) afforded 1,2-bis(7-[(z)-methoxycarbonylmethylen]-5, 6-dihydro-5H-6-one-[1,2,4]triazolo[3,4-b] [1,3,4] thiadiazin-3-yl)-ethan-1,2-diol 4 and 1,2-bis (7-[(z)-ethoxycarbonylmethylen]-5,6-dihydro-5H-6-one-[1,2,4]triazolo[3,4-b][1,3,4]thiadiazin-3yl)-ethan-1,2-diol 5, respectively. The reactions took place with the addition of $\mathrm{SH}$ and $\mathrm{NH}_{2}$ groups of the compound $\mathbf{3}$ to acetylene bond and $\mathrm{C}=\mathrm{O}$ groups of DMAD and DEAD by Michael type addition and OMe elimination. TLC and the NMR spectrum of compound $\mathbf{4}$ and $\mathbf{5}$ showed that only a single, pure compound was present. The structure of these compounds was determined by NMR, IR, Mass spectra and microanalysis. The mass spectrum of $\mathbf{4}$ (which showed a peak at $m / z, 510$ that is characteristic for the molecular ion) are in agreement with the molecular formula of $\mathrm{C}_{16} \mathrm{H}_{14} \mathrm{~N}_{8} \mathrm{O}_{8} \mathrm{~S}_{2}$. The ${ }^{1} \mathrm{H}$ NMR spectra of $\mathbf{4}$ showed two exchangeable protons ( $\mathrm{OH}$ and $\mathrm{NH}$ protons). The hydroxyl proton of $\mathrm{CHOH}$ resonated at higher field than that of the $\mathrm{NH}$ proton, which were assigned to the singlets at $\delta 4.14$ and $\delta 7.27 \mathrm{ppm}$, along with a sharp singlet 
signal from the exomethylene proton $\mathrm{C}=\mathrm{CH}$ in the region $\delta 6.96 \mathrm{ppm}$. The ${ }^{13} \mathrm{C}$ NMR spectrum of $\mathbf{4}$ showed two types of signals. In the downfield region six signals were assigned for the heterocyclic ring carbon atoms, $\mathrm{CH}=\mathrm{C}$ and $\mathrm{C}=\mathrm{O}$. In the upfield region only two signals of $\mathrm{CHOH}$ and $\mathrm{OMe}$ resonated. The various methods that have been applied for the synthesis of [1,3] thiazolo[2,3-c][1,2,4]triazol involve mainly the construction of the fused ring from functionalized derivatives of either 1,3-thiazole ${ }^{17-19}$ or 1,2,4-triazole ${ }^{20}$. Thus, treatment of tartaric acid with thiosemicarbazide 6 caused a ring closure to form 1,2-bis(5-mercapto- $4 \mathrm{H}$ 1,2,4-triazol-3-yl)-ethane-1,2-diol 7 (Scheme 2). The structures were deduced from the respective spectral data. The IR spectra of compound 7 showed characteristic absorption band due to the $\mathrm{NH}\left(3150 \mathrm{~cm}^{-1}\right)$. The elemental analysis and the mass spectral data of 7, which showed a molecular ion peak at $m / z 260$ as the base peak, led to the assignment of the molecular formula $\mathrm{C}_{6} \mathrm{H}_{8} \mathrm{~N}_{6} \mathrm{O}_{2} \mathrm{~S}_{2}$. Reaction of compound 7 with DMAD afforded 1,2-bis $(6-[(z)-$ methoxycarbonylmethylen]-5-oxo-[1,3]thiazolo[2,3-c][1,2,4] triazol-3-yl)-ethan-1,2-diol $\mathbf{8}$. The structure of this compound was determined by NMR, IR, Mass spectra and microanalysis. The mass spectrum of this compound displayed a molecular Ion peak at appropriate $m / z 480$. The ${ }^{1} \mathrm{H}$ NMR spectrum of compound 8 showed only one exchangeable proton; an $\mathrm{OH}$ resonance appeared in $\delta 5.07 \mathrm{ppm}$. The singlet of the $\mathrm{C}=\mathrm{CH}$ proton was shifted to the region at $\delta 6.60 \mathrm{ppm}$. The singlet of the $\mathrm{CH}$ group was assigned to the signal at $\delta 5.23 \mathrm{ppm}$. The IR spectrum of the reaction product $\mathbf{8}$ showed two CO groups stretching at 1715 and $1680 \mathrm{~cm}^{-1}$.

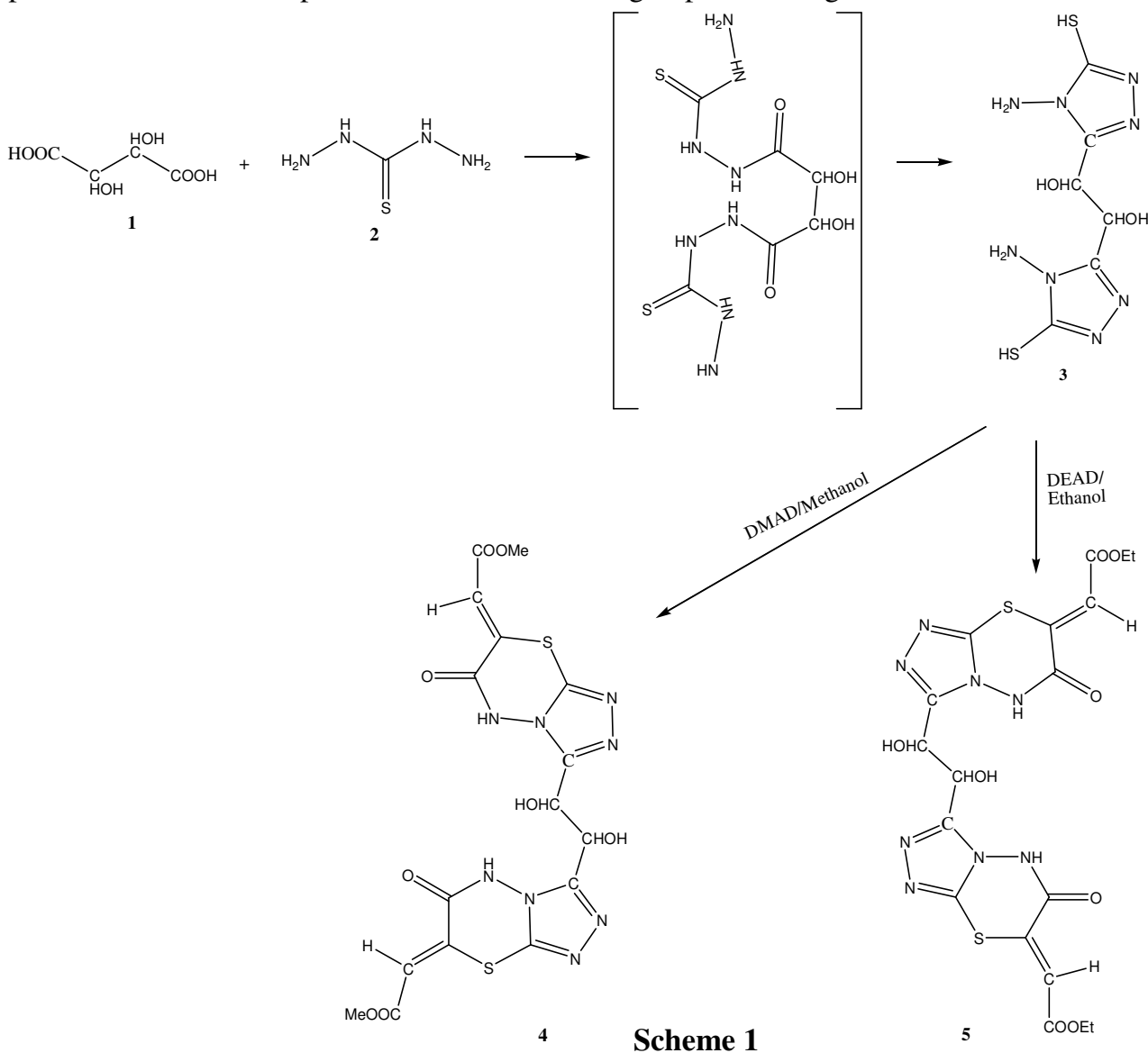


<smiles>NNC(N)=S</smiles><smiles>CC(=S)NNC(=O)C(O)C(=O)NNC(C)=S</smiles><smiles>OC(c1n[nH]c(S)n1)c1n[nH]c(S)n1</smiles><smiles>CC(=O)/C=c1\sc2nnc(C(O)CO)n2c1=O</smiles>

Scheme 2

In summary, the presented reactions carried the advantage of being performed under mild conditions and good yields. These compounds could be intrusting in pharmacology and biology.

\section{References}

1. Ates O, Kocabalkanli A, Sanis G O, Ekinci A and Vidin A, Drug Res., 1997, 47, 1134.

2. Zheng X Li Z, Wang Y, Chen W, Huang Q, Liu C and Song G, J Flurine Chem., 2003, 123, 163-169.

3. Amir M and Shikha K, Eur J Med Chem., 2004, 39, 535-545.

4. Palaska E, Sahin G, Kelicen P, Durlu NT and Altinok G, Farmaco, 2002, 57(2), 101-107.

5. Lee A R T, U.S. Patent, 1996, 5498720.

6. Udupi R H and Bhat A R, Indian J Heterocycl Chem., 1996, 6(1), 41.

7. Bayer H O, Cook R S and Von Meyer W C S, Afr Pat., 1971, 7 004, 373.

8. Temple C, Triazoles-1,2,4-, in Montgomery J A, (Ed.), The Chemistry of Heterocyclic Compounds, John Wiley and Sons, New York, 1981.

9. Zeeh B, Buschmann H and Jung J, Eur Pat., 1981, 21076.

10. Zeeh B, Goet N, Ammermann E and Pommer E H, Ger Pat., 1981, 2 926, 280.

11. Paolo F, Daniele S, Franca S and Noemi P, Farmaco, 1996, 51, 659-664.

12. Hoggarth E, J Chem Soc., 1952, 4811. 
13. Ajello E, Migliara O and Sprio V, J Heterocycl Chem., 1972, 9, 1169-1170.

14. Potts K T and Huseby M R, J Org Chem., 1966, 31, 3528-3531.

15. Kurzer K and Wilkinson M, J Chem Soc., 1969, C, 1218.

16. Moustafa A H, Haggam R A, Younes M E and El-Ashry E S H, Nucleosides, Nucleotides Nucleic Acids, 2005, 24(10-12), 1885-1894.

17. El-Sherif H A H, Mahmoud A M, Sarhan A A O, Hozien Z A and Habib O M A, $J$ Sulfur Chem., 2006, 27(1), 65-85.

18. Lesyk R, Vladzimirska O, Holota S, Lucjusz Zaprutko I and Gzella A, Eur J Med Chem., 2007, 42(5), 641-458.

19. Shestakov A S, Gusakova N V and Imoshkina A G T, Russ J Org Chem., 2007, 43, 1825.

20. Mamedov V A, Valeeva V N and Antokhina L A, Chem Heterocycl Comp., 1995, 31(3), 355-358. 


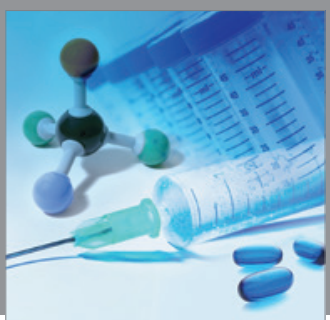

International Journal of

Medicinal Chemistry

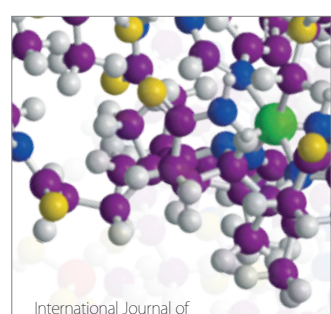

Carbohydrate Chemistry

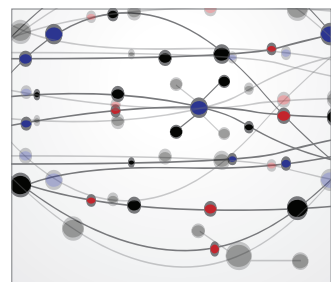

The Scientific World Journal
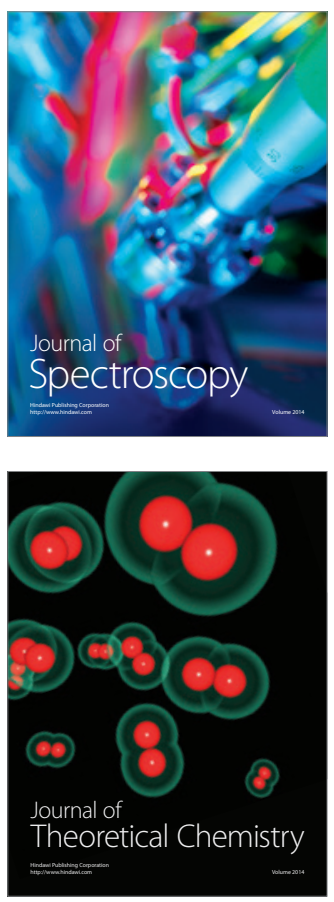
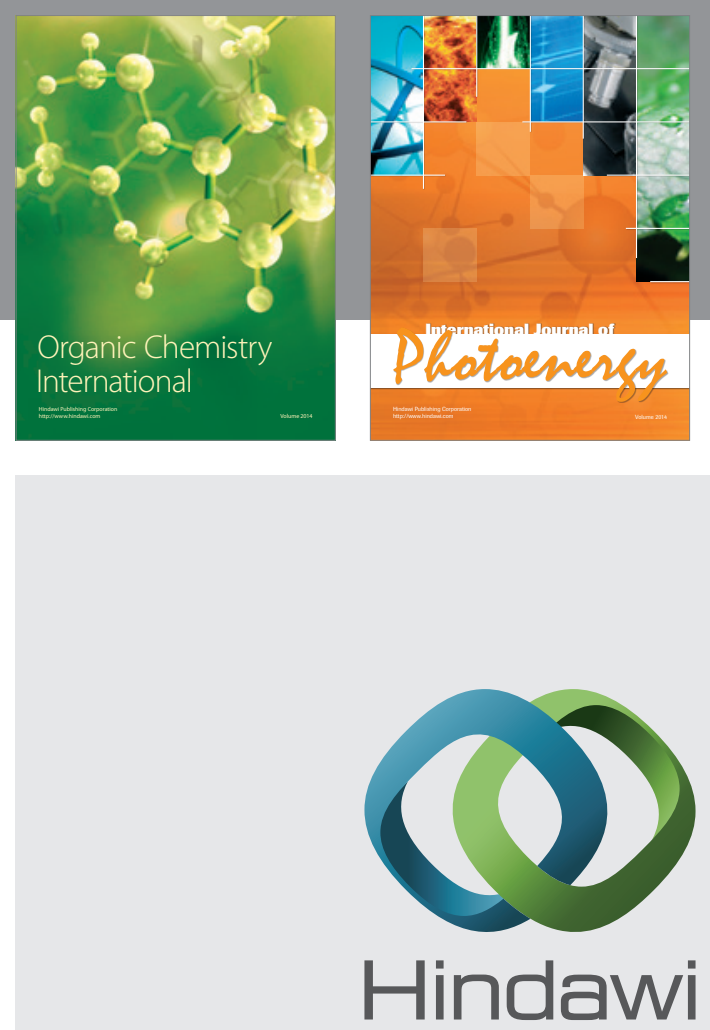

Submit your manuscripts at

http://www.hindawi.com
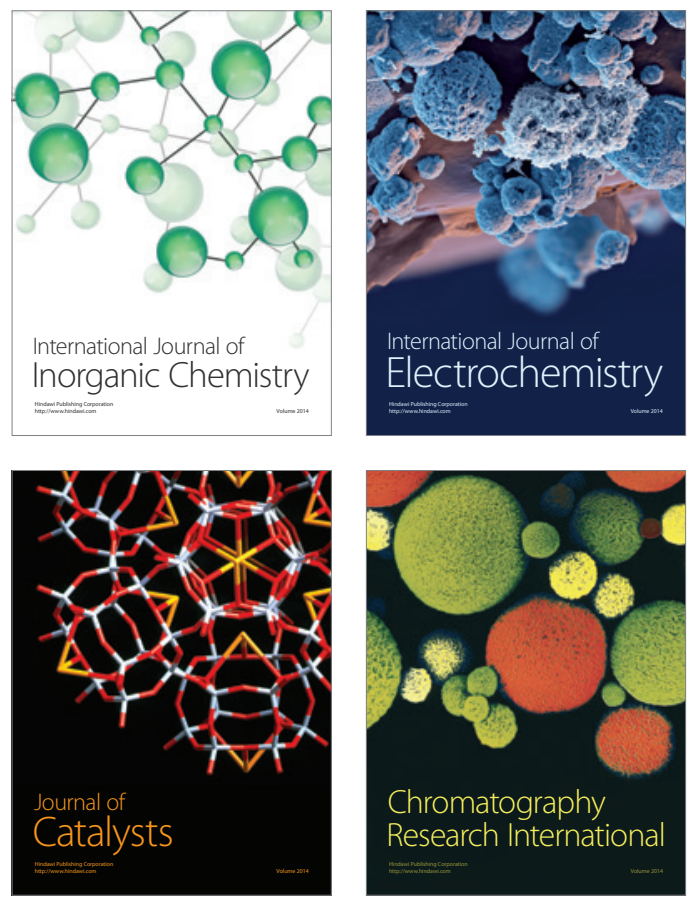
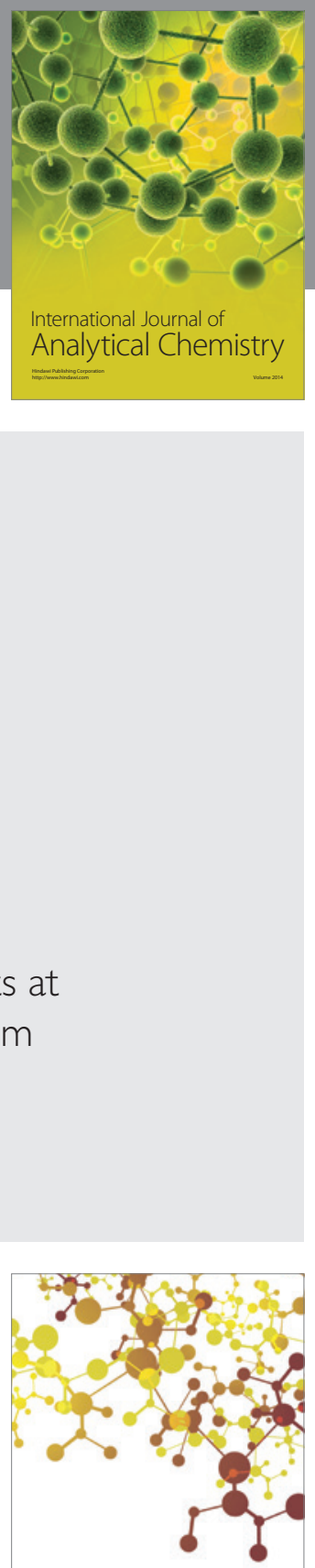

Journal of

Applied Chemistry
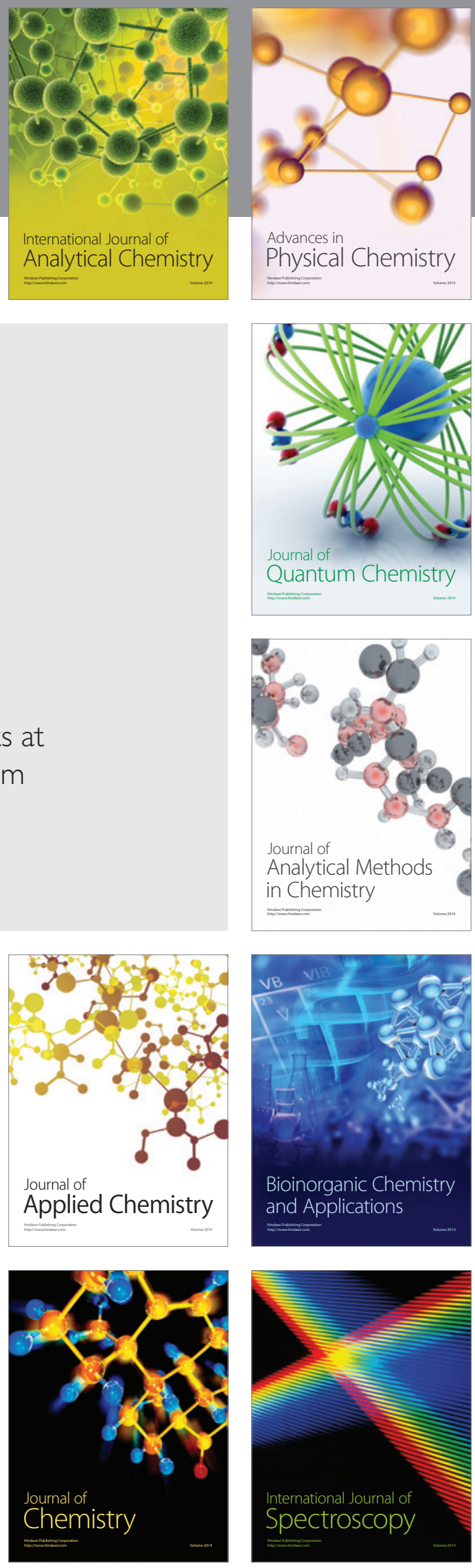